\title{
Parkinson's Disease: Insights from the Laboratory and Clinical Therapeutics
}

\author{
Jing-ye Zhou, Yong Yu, Xian-Lun Zhu, \\ Chi-Ping $\mathrm{Ng}$, Gang $\mathrm{Lu}^{*}$ and Wai-Sang Poon \\ Division of Neurosurgery, Department of Surgery, \\ The Chinese University of Hong Kong, Hong Kong, \\ China
}

\section{Introduction}

Parkinson's disease (PD), a neurodegenerative disorder that was first described by James Parkinson (1755-1824) in 1817, is characterized partly by a progressive loss of dopaminergic neurons in the substantia nigra pars compact. It affects approximately $1.5 \%$ of the global population over 65 years of age. PD is the type of Parkinsonism that is defined as any combination of six specific and independent motoric features: bradykinesia, resting tremor, rigidity, loss of postural reflexes, flexed posture and the freezing phenomenon. Current dopamine replacement strategies, which include levodopa (L-DOPA, the precursor of dopamine) and dopamine receptor agonists, as well as monoamine oxidase B and catechol O-methyltransferase inhibitors, can effectively improve these symptoms. Many reviews of this field are available elsewhere; therefore we focus here on the most recent outcomes regarding the identification of key biomedical progress in $\mathrm{PD}$, describe the most promising biological research targets that are currently being assessed to find ideal treatments, and provide insights from progress in laboratory research and clinical therapeutics.

\section{The pathogenesis of Parkinson's disease}

Decades of research have not found a single cause for PD and therefore a single factor is unlikely to emerge. Current research is mainly carried out on animal models of PD induced by intoxication with 1-methyl-4-phenyl-1,2,3,6-tetrahydropyridine (MPTP) and models of postencephalitic parkinsonism, neither of which has fully reproduced the clinical and pathological features of true PD. However, it is believed that PD is a multifactorial disease caused by both environmental factors and genetic susceptibility. Aging is an obvious factor because PD mainly targets elderly people. Studies have shown that the incidence of PD is around 10-15 cases per 100000 person-years (1), but this figure increased to 93.1 in people aged between 70 and 90 years (2). Male sex appeared to be another risk factor, because the incidence of PD in men was 1.5 times higher than that in women (3). Geographically, China has a similar prevalence of PD to western countries (4), whereas Africans have a lower rate compared with African Americans (5).

${ }^{*}$ Corresponding Author 


\subsection{Environmental factors}

Many environmental factors may increase the risk of developing PD. Priyadarshi et al. (6-7) showed the association between PD and farming, professional pesticide use, and drinking well-water in a meta-analysis. Other environmental factors, such as metals, solvents, electromagnetic fields and lifestyles, have also been determined as possible risk factors (8). Studies over the past two to three decades have provided more supportive findings. Tanner and Goldman (9) linked the consumption of well-water to the occurrence of PD. Living in rural areas was associated with farming and pesticide use, which led to an increased incidence of PD patients (10-11). This was association was clarified by another study that demonstrated that the effect of pesticide use was independent from that of farming (12). A lifestyle study found similar evidence of increased herbicide exposure in patients with PD (13). The discovery that exposure to MPTP induced parkinsonian syndromes initiated a new field in PD research - the study of exposure to pesticides (14-15). Many different pesticides have been investigated. MPTP has a similar structure to paraquat, a herbicide that is widely used in many countries. Paraquat was found to be associated with PD based on a 20-year exposure study (16). In a study in Germany, organochlorine pesticides were identified as risk factors for PD (17). Dithiocarbamates, which have been shown to enhance MPTP toxicity (18), were considered to be another risk factor for PD (19). Manganese, a constituent of several pesticides and herbicides, induced parkinsonism in humans following chronic exposure (20). Pesticides and herbicides may be used in combination, which results in a higher level of toxicity. One study showed that exposure to paraquat plus manganese ethylenebis-dithiocarbamate (maneb) resulted in 4.17-fold greater risk for PD compared with unexposed populations (21).

In addition to the above agricultural risk factors, industrial factors also play an important role in the development of PD. Chronic exposure to copper, manganese, and lead was associated with the risk for PD (22) and PD patients who had worked in factories that used chemicals, iron or copper had higher death rates (23). A German study also reported an association between exposure to lead and PD (17). Furthermore, the relationship between PD and head trauma has been investigated: a history of head trauma was associated with onset of PD at an earlier age (24-25).

As discussed above, many risk factors are involved in the development of PD; however, two environmental factors could lower this risk: cigarette smoking (26) and coffee drinking (27), although their mechanisms are unknown. Studies of twins showed an inverse association between cigarette smoking and PD (28-29), and similar results were reported by a study that compared PD cases with their unaffected siblings (30). A meta-analysis reported an inverse association between PD and coffee drinking which was independent of smoking (31). However, this was seen in men but not in women (27).

\subsection{Genetic susceptibility}

Most cases of PD are sporadic, but some patients (10-15\%) show a positive familial history of the disease (32). Although the cause of PD is still unknown, both environmental and genetic factors are considered to be important. The discovery of several causative mutations and genes (33) has allowed a better understanding of PD. 


\subsection{1 $\alpha$-Synuclein (PARK1)}

$\alpha$-Synuclein, also called PARK1, was the first gene to be linked to PD (34), and mutations in $\alpha$-synuclein gene have been linked to rare cases of familial PD (35-37). Genomic multiplications have been reported and both mRNA and protein levels of $\alpha$-synuclein were increased in the brain (38). However, a large screening study has shown that $\alpha$-synuclein multiplication is a rare cause of parkinsonism (39). Nevertheless, there is a link between $\alpha-$ synuclein level and age at onset and severity: when $\alpha$-synuclein duplication causes the disease at an earlier age, then PD has a more aggressive form (39-40). $\alpha$-Synuclein is a small neuronal protein that is involved in neurotransmitter release and synaptic vesicle recycling. Without genetic changes, $\alpha$-synuclein is an abundant protein and a major component of Lewy bodies (LBs) in idiopathic, apparently sporadic PD (41-42). This supports the role of $\alpha$ synuclein in the pathogenesis of PD.

\subsubsection{Parkin (PARK2)}

The PARK2 gene was identified as parkin in autosomal recessive forms of familial juvenileparkinsonism (AR-JP) (43). AR-JP is most commonly seen in Japanese populations and typically has an onset before the age of 40 years (44-45). Interestingly, no LBs have been found in parkin-positive brains. Parkin was reported to act as an E3-ubiquitin ligase that targets cytoplasmic proteins for proteasomal degradation and plays a role in receptor trafficking (46-47). A wide variety of parkin mutations have been found including large homozygous deletions in exons (43); frame-shift mutations, point mutations, duplications and triplications of exons (48); and deletions in the promoter (49). Parkin mutations were identified in nearly $50 \%$ of familial cases with disease onset before the age of 45 years (50) and in $15 \%$ of sporadic young-onset cases (51). In the subset of cases with onset before the age of 20 years, this proportion increased to $70 \%$ (51).

\subsubsection{Ubiquitin carboxyl-terminal hydrolase L1 (UCH-L1; PARK5)}

$\mathrm{UCH}-\mathrm{L} 1$ is an enzyme that hydrolyzes the C-terminus of ubiquitin to generate ubiquitin monomers that can be recycled to clear other proteins. A single missense mutation in $\mathrm{UCH}-$ L1 was reported in two siblings with typical PD in a German family (52). A second rare mutation was reported in French families but was not restricted to PD (53). No other carriers of this mutation and no other mutations in UCH-L1 have been identified (54-55), which has raised doubts about the relevance of UCH-L1 to PD.

\subsubsection{PTEN-induced kinase 1 (PINK1; PARK6)}

PINK1 encodes a widely expressed protein kinase that is localized in mitochondria. PINK1 is the second most common cause of AR-JP (56) and may play an important role in sporadic PD (57). Several mutations have been identified including transitions (56), single heterozygous mutations (57), and heterozygous deletion of the PINK1 gene plus a splice site mutation on the remaining copy (58). One study suggested that heterozygous mutations are a significant risk factor in the development of PD (59). Briefly, PINK1 mutations may cause loss of function in patients with recessively inherited forms of PD because most mutations fall in the kinase domain (60). 


\subsubsection{Oncogene DJ-1 (PARK7)}

The DJ-1 gene encodes a ubiquitous and highly conserved protein, and has been identified as a causative gene for early-onset autosomal recessive PD (61). A couple of mutations have been reported but these were found in only a few patients with early-onset PD (61-62). DJ-1 protein is not an essential component of LBs but is localized in mitochondria that protect against neuronal death (63).

\subsubsection{Leucine-rich repeat kinase 2 (LRRK2; PARK8)}

LRRK2 mutations are the most common mutations identified in either familial or sporadic PD. Although other LRRK2 mutations have been described, the G2019S mutation has been found to be the most common pathogenic cause of PD, and has been reported in $5-6.6 \%$ of cases of autosomal dominant PD (64-65) and 2-8\% of sporadic cases (66-67). Penetrance in G2019S patients was age dependent, and increased from $17 \%$ at the age of 50 years to $85 \%$ at the age of 70 years (68). Nigral neuron loss and LB formation have been observed in the brains of sporadic PD patients with G2019S mutations (66).

\subsubsection{Adenosine triphosphatase type 13A2 (ATP13A2; PARK9)}

ATP13A2 has been identified as the causative gene in Kufor-Rakeb syndrome (69), a rare form of juvenile-onset parkinsonism caused by autosomal recessive neurodegeneration. Studies in PD patients have reported mutations of 22bp duplication in exon 16 (70) and missense mutation in exon 15 (71), indicating that they are possible causes of PD.

\subsubsection{OMI/HTRA serine peptidase 2 (OMI/HTRA2; PARK13)}

A missense mutation in the OMI/HTRA2 gene has been found in sporadic PD patients (72). The OMI/HTRA2 gene is located within the PARK3 linkage region, but its role in PD is unknown.

Other genetic factors, such as glucocerebrosidase (73), microtubule-associated protein tau (74) and progranulin (75), have shown an association with PD but their causality has yet to be elucidated.

\section{Experimental models in PD research}

\subsection{Neurotoxin models}

The development of experimental models is essential for a better understanding of the etiopathogenesis of PD and to provide effective therapeutic agents. Neurotoxins that target the dopamine (DA) system, such as 6-hydroxydopamine (6-OHDA) and MPTP were used in early animal models for PD research and are still widely in current use (76).

\subsubsection{6-OHDA}

6-OHDA was the first agent used in an animal model of PD (77). Because of its structural similarity to DA and norepinephrine, 6-OHDA can enter and accumulate in both dopaminergic and noradrenergic neurons. Catecholaminergic structures are destroyed by 6- 
OHDA through reactive oxygen species (ROS) and quinines (78-79). Because 6-OHDA crosses the blood-brain barrier (BBB) poorly, it is usually injected directly into the brain stereotaxically. Intraventricular and intracisternal administrations of 6-OHDA to rats produce a bilateral loss of DA and motor abnormalities that can be partially corrected by dopaminergic receptor agonists (80). However, the motor deficits induced are caused by considerable depletion of DA that requires high doses of 6-OHDA. Thus, animals often die due to aphagia and adipsia from severe stress $(77,81)$. In contrast, a unilateral intracerebral injection is more practical and useful. This model provides an approach to measure asymmetrical turning behavior in response to DA agonists with an internal control - the unlesioned contralateral side of the brain. To induce unilateral lesions, 6-OHDA is typically injected into the striatum, substantia nigra or the median forebrain bundle. Striatal injection of 6-OHDA produces slow retrograde degeneration of the nigrostriatal system over 1 month (82) and apoptotic morphology in the neurons that die (83-84). After injection of 6-OHDA into the substantia nigra or the medial forebrain bundle, dopaminergic neurons die more quickly than after striatal injection and no apoptotic morphology is seen (85). It should be noted that no typical LB formation has been demonstrated in this model (86). Unilateral lesions produce typical asymmetric circling motor behavior, especially after injection into the substantia nigra or the medial forebrain bundle which leads to more readily detectable behavioral deficits. The quantification of this circling behavior has been applied widely to evaluate new anti-parkinsonian drugs, and stem-cell and gene therapies (86).

6-OHDA has mainly been used in small animals, such as rodents, but has also been administered to non-human primates (86) and has been applied in vitro in various different models (87). The unilateral lesion induced by 6-OHDA in rats is one of the most popular models of PD (88-89). This model has advantages for testing cell replacement therapies and investigating regenerative therapies (90). However, 6-OHDA models demonstrate only one dimension of a complex illness: one type of cell loss and cellular stress. Moreover, 6-OHDA causes an acute model and cannot replicate many features of PD (90).

\subsubsection{MPTP}

MPTP was discovered in the early 1980s (14). Unlike 6-OHDA, MPTP is highly lipophilic and can cross the BBB easily after systemic administration. In the brain, it is metabolized to the 1-methyl-4-phenylpyridinium ion $\left(\mathrm{MPP}^{+}\right)$, which can enter dopaminergic neurons via the DA transporter (DAT) (91), and results in mitochondrial complex I inhibition and ROS formation (92). No LBs have been observed in MPTP-induced parkinsonism in either human or animal models (93-94).

Systemic administration of MPTP to many different species satisfies most of the requirements for an ideal parkinsonian model (90). The most commonly used PD model is the MPTP mouse model cause of the relatively low cost and acceptable timing for research. Acute administration of MPTP caused depletion in striatal DA (95), whereas the subacute model showed striatal DA depletion and cell loss in the substantia nigra (96-97). However, the acute model showed a greater loss of striatal DA than the subacute model. Moreover, the mechanism of cell death appears to differ in these two models: non-apoptotic mechanisms after acute (98) versus apoptotic mechanisms after subacute administration of MPTP (99). In addition, Acute treatment of animals with MPTP induced clear microglial activation in the striatum and the substantia nigra (100-101) and over-expression of inducible nitric oxide 
synthase (102), whereas the subacute model showed only minimal microglial activation (101). Consequently, anti-inflammatory and anti-microglial compounds could be potential neuroprotective agents for PD and have been investigated using the acute MPTP model.

Although the mouse model has been used extensively in PD research, the non-human primate model is considered to be the "gold standard" for assessment before clinical trials because it reproduces the main pathological defect of PD, and the parkinsonian symptoms induced match many clinical features of PD. Acute and chronic non-human primate models are available, and both show similar motor symptoms of parkinsonism, although the mechanisms differ. Schneider et al. reported that the acute MPTP monkey model inuced increased binding to striatal DA D1 and D2 receptors and increased striatal prepronkephalin mRNA expression. In contrast to these findings, striatal preprotachykinin mRNA expression was decreased in both acute and chronic MPTP monkey models. Notablely, chronic administration of MPTP to animals with cognitive but no motor deficits induced no changes in preprotachykinin expression in the striaturn (103).

MPTP has been used to produce the best-characterized model of PD (104) in many different species, including non-human primates, small vertebrates, such as mice, and even invertebrates, such as worms (105-107). However, rats are relatively resistant to MPTPinduced neurotoxicity compared with mice (108-109) and primates are the most sensitive model (110). MPTP models develop pathological and neurochemical changes similar to those of PD patients (111) and produce an irreversible and severe parkinsonian syndrome that includes rigidity, tremor, bradykinesia, posture abnormalities and even freezing (86, 112). PD is a slowly progressive illness but the MPTP mouse model is an acute or subacute process. The chronic administration of MPTP to primates induced the slow development of a parkinsonian syndrome (113).

\subsubsection{Rotenone}

Rotenone is one of the most recent neurotoxins to be used in PD models (114). It is widely used as an insecticide throughout the world, and the rotenone model was the first to use an environmental toxin. Rotenone is highly lipophilic and can thus move freely and rapidly across cellular membranes without transporters. In mitochondria, it interferes with the electron transport chain, resulting in mitochondrial complex I inhibition (115). Furthermore, it also inhibits the formation of microtubules from tubulin (116) and the excess of tubulin monomers may be toxic to cells (117). The complex I inhibition induced by rotenone led to increased levels of oxidative stress which occurred predominantly in dopaminergic regions including the striatum, ventral midbrain and the olfactory bulb (118). Rotenone is a mitochondrial complex I inhibitor and acts evenly throughout the brain (119), which indicates that dopaminergic neurons are uniquely sensitive to mitochondrial complex I inhibition. Sherer et al (120) detected microglial activation in the striatum and substantia nigra of rotenone-infused rats. In the same model, the hallmark of PD pathology - LBs were observed $(114,121)$ in the ventral midbrain regions (122). Exposure of animals to rotenone caused selective nigrostriatal dopaminergic neurodegeneration but had minimal effects on neurons of other brain regions $(114,121)$. It has been reported that parkinsonian symptoms in humans, such as rigidity and bradykinesia, are caused by reduced striatal dopaminergic activity (123); this change in motor behavior has also been reported in rotenone-exposed rats $(114,121)$. Rats treated with rotenone displayed a significant increase in abnormal motor behavior and decline in locomotor activities (124). 
Rotenone-treated animal models reproduce all the pathological and behavioral features of typical human PD. Rotenone has been used successfully in a variety of species, including non-human primates, mice, and snails. However, there is some variation between the models and not all treated rats displayed these features. Briefly, this model provides very similar clinical features to typical PD but the low reproducibility and high mortality rate (88) may limit its practical use (117). Interestingly, rotenone was found to be involved in a multisystem disorder (125): enteric nervous system dysfunction (126) and loss of myenteric neurons in rats (127).

\subsubsection{Other neurotoxins}

Other neurotoxins used in PD models include paraquat and maneb. Paraquat is a common herbicide, has a similar chemical structure to $\mathrm{MPP}^{+}$, the oxidized metabolite that mediates MPTP neurotoxicity, and has been suggested to be a risk factor for PD (128). Epidemiological studies have also indicated that exposure to paraquat may play an important role in the development of PD (16). After crossing the BBB, paraquat inhibits mitochondrial complex I in dopaminergic neurons (129). The treatment of mice with paraquat caused destruction of dopamine neurons in the substantia nigra (130). The paraquat-induced neurodegeneration is probably triggered by c-Jun N-terminal kinase signaling pathways (131). In this model, microglial activation has been identified and may act as a risk factor for dopaminergic cell death (132). Further investigations showed that the activated microglia produce potentially harmful molecules, such as superoxide anion and nitric oxide, resulting in redox cycling reactions and ROS formation which enhance tissue vulnerability in the paraquat model (133-135). In addition, oxidative stress plays an important role in nigrostriatal degeneration (136-137). The paraquat model demonstrated $a-$ synuclein up-regulation and aggregation associated with dopaminergic cell death in the substantia nigra pars compacta in mice (138).

Maneb is a fungicide that is always used in combination with paraquat in agriculture. In PD research, maneb potentiates the DA toxicity of paraquat in mice (139). Maneb alone inhibits mitochondrial complex III and causes selective dopaminergic neurodegeneration (140). The combination of maneb and paraquat induced more pronounced behavioral and pathological changes than paraquat alone (141-142). Barlow et al. (143) explained that this effect could be due to the ability of maneb to modify the biodisposition and thus increase the concentration of paraquat. Findings in co-exposure models have important implications for the risk of PD in humans because they are liable to be exposed to the synergistic mixtures in agricultural or residential areas where both agents are applied jointly (139).

As a model of environmental exposure, administration of paraquat/maneb reproduces neurodegenerative changes and is useful for the investigation and understanding of the neurotoxic mechanisms of risk factors for PD. Although this model cannot achieve the severe nigrostriatal neurodegeneration induced by MPTP and 6-OHDA, it is a good complement for the comprehensive understanding of PD.

\subsection{Genetic models}

The majority of PD cases are sporadic but several causative genes and mutations have been discovered and have led to new approaches in the investigation of the mechanisms involve in PD. Several genetic animal models of PD reported in recent years are discussed below. 


\subsection{1 $\alpha-S y n u c l e i n$}

Many different transgenic mice models that over-express human a-synuclein have been generated and applied to pathogenesis and drug research. Transgenic mice induced by the tyrosine hydroxylase promoter expressed a-synuclein containing A30P and A53T mutations and showed a progressive decline in locomotor activity and loss of substantia nigra neurons and striatal DA content (144-145). When transgenic mice were induced by the neuronspecific platelet-derived growth factor $\beta$ promoter, a-synuclein over-expression was observed, together with reduced tyrosine hydroxylase immunoreactivity and DA content in the striatum and impaired motor performance (146). Mice that over-expressed A53T mutant a-synuclein under the mouse prion promoter $(\mathrm{PrP})$ developed an adult-onset progressive neurodegenerative disorder (147-148). Another neuron-specific promoter, thymocyte differentiation antigen 1 (Thy1), was used in mice to induce a high level of widespread expression of a-synuclein in most neuronal populations (149-150). Both Thy-1 and PrP mice are the only models that have intraneuronal inclusions, degeneration and mitochondrial DNA damage in the neurons (151).

A rat model that over-expresses wild-type or mutant a-synuclein induced by adenoassociated viruses in substantia nigra neurons, displayed progressive age-dependent loss of DA neurons, motor impairment, and a-synuclein-positive cytoplasmic inclusions (152). In Drosophila, a-synuclein over-expression led to age-dependent loss of dorsomedial dopaminergic neurons, accumulation of LB-like inclusions with a-synuclein immunoreactivity and compromised locomotor activity (153). a-Synuclein over-expression in Caenorhabditis elegans caused accelerated dopaminergic neuronal loss and motor impairment (154-155).

PC12 cells have been widely used in PD research to understand the regulation of the neuronal level of a-synuclein. a-Synuclein expression in PC12 cells was low but could be greatly increased by treatment with nerve growth factor (NGF) (156). NGF signal transduction was indicated via the MAP/ERK and PI3 kinase pathways (157). Another study with PC12 cells reported that wild-type a-synuclein was selectively translocated into lysosomes and degraded by the chaperone-mediated autophagy pathway (158). However, the mutant a-synuclein bound to the receptor on the lysosomal membrane inhibited both its own degradation and that of other substrates (158). PC12 cells over-expressing mutant asynuclein showed impaired proteasomal activity and enhanced sensitivity to proteasomal inhibitors (159). Endoplasmic reticulum stress and mitochondrial dysfunction played important roles in increased cell death (160). The same model in another study showed impairment in both proteasomal and lysosomal functions, a high level of autophagic cell death and loss of chromaffin granules (161).

Yeast has been widely used to investigate the role of a-synuclein toxicity in human diseases, including PD. When expressed in yeast, a-synuclein became cytotoxic in a concentrationdependent manner (162). a-Synuclein in yeast was highly selectively associated with the plasma membrane and formed cytoplasmic inclusions (162). The growth inhibition induced by a-synuclein was accompanied by cellular consequences, such as proteasome impairment, heat-shock and oxidative stress, formation of ubiquitin-positive a-synuclein inclusion bodies, and emergence of apoptotic markers (162-164). Because the molecules that inhibit asynuclein toxicity are potential therapeutic agents, a-synuclein toxicity in the yeast model has been used for genetic screening to identify genetic modifiers (165-166) and for small molecule or chemical screening to identify novel compounds. 
Studies of a-synuclein in cell-free systems have focused on its aggregation pathway, posttranslational modification, self-assembly and structure characterization. Test-tube models are critical for the investigation of PD-related protein a-synuclein and its related molecules as they provide more detailed information than any other approaches. However, some findings may not fully account for the biological complexity of a-synuclein in vivo. Therefore, further validation in cell cultures or in vivo is required.

\subsubsection{Parkin}

Parkin mutations have been found in a number of cases with recessive juvenile onset (167) and are the second genetic cause of PD. In a rat model, over-expression of parkin protected against the toxicity of mutant a-synuclein as demonstrated by a reduction in a-synucleininduced neuropathology (168). In addition, parkin over-expression through viral transduction protected mice from mild MPTP-induced lesions (169). However, parkin knockout mice showed no impairment in the dopaminergic system (170-171). A parkin knockout Drosophila model exhibited locomotor defects and male sterility (172). These tissue-specific phenotypes were due to mitochondrial dysfunction. Further studies showed that oxidative stress components and genes involved in innate immunity were induced in parkin mutants, which indicated that oxidative stress and/or inflammation may play a fundamental role in the etiology of AR-JP (173). Another study showed that the expression of mutant human parkin in Drosophila caused age-dependent, selective degeneration of dopaminergic neurons accompanied by progressive motor impairment (174). Both the loss of function and toxicity of parkin have been demonstrated in the Drosophila model.

In experiments using cell-free models, mutant forms of parkin associated with AR-JP were reported to have reduced ubiquitin ligase activity (175-176). Catechol-modified parkin in the substantia nigra - a vulnerability of parkin to modification by dopamine - suggested a mechanism for the progressive loss of parkin function in dopaminergic neurons (177). Another modification - phosphorylation by cyclin-dependent kinase 5 - may contribute to the accumulation of toxic parkin substrates and decrease the ability of dopaminergic cells to cope with toxic insults in PD (178).

\subsubsection{PINK1}

PINK1 knockout mice had no dramatic abnormalities in the dopaminergic system (179). In Drosophila models, compared with the loss of parkin, the loss of PINK1 showed a strong similarity in phenotype: shortened lifespan, infertility and wing postural defect; in addition, identical loss of mitochondrial integrity was found in both cases (180-182). However, one difference was also observed: up-regulation of parkin rescued PINK1 mutants, whereas PINK1 up-regulation could not rescue parkin mutation (180-182). Cell-free models have been used to investigate the enzymatic function of PINK1 and the effects of mutations.

PINK1 was shown to phosphorylate downstream effector tumor necrosis factor receptorassociated protein 1 directly and prevent oxidative stress-induced apoptosis (183). It was also reported that the PINK1 kinase domain catalyzed the phosphorylation of artificial protein substrates, including a-casein (184) and histone H1 (60). Kinase assays suggested that multiple PINK1 mutants associated with autosomal recessive PD have reduced kinase activity $(60,183-185)$. 


\subsubsection{DJ-1}

DJ-1 knockout mice exhibited a deficit in scavenging mitochondrial hydrogen peroxide due to its function of atypical peroxiredoxin-like peroxidase (186). Further studies have been carried out using Drosophila. DJ-1 knockout caused selective sensitivity to the oxidative toxins, paraquat and rotenone (187-189). DJ-1 protein undergoes oxidative modification on cysteine residue, which was also seen in Drosophila (189), and the oxidative modification occurred with aging and after exposure to paraquat (190). Cell-free models have helped researchers to characterize the crystal structure of DJ-1, investigate its function and activity, and reveal the effect of oxidative modifications on the stability and function of DJ-1.

\subsubsection{LRRK2}

In cell models, LRRK2 mutations significantly increased autophosphorylation activity (191194). Over-expression of mutant LRRK2 caused condensed and fragmented nuclei, resulting in increased cellular toxicity (191). Because the cellular toxicity induced by mutant LRRK2 can be prevented by inactivation of the kinase domain in cell models, the kinase domain could be a therapeutic target for LRRK2-associated PD. Cell-free systems have been used to investigate the kinase function and how it is affected by pathogenic mutations. Reports indicated that LRRK2 catalyzed its autophosphorylation or the phosphorylation of artificial substrates (191-192, 195). This suggested that LRRK2-mediated phosphorylation was regulated by the binding of guanine triphosphate (GTP); in addition, both GTP binding and protein kinase activity are necessary for LRRK2 neurotoxicity $(192,196)$.

\section{Clinical therapeutic insights}

From the traditional view, PD is considered to be a single clinical entity, but this is currently under scrutiny (197-198). Clinically, the subtypes of this heterogeneous disease can be recognized on the basis of age at onset, predominant clinical features and progression rate. There are two major clinical subtypes: the tremor-predominant form which is often observed in younger people, and generally leads to a slow decline in motor function; in the other type, known as "postural imbalance and gait disorder" that is often observed in older people (>70 years old), motor function declines more rapidly, and is characterized by akinesia, rigidity, and gait and balance impairment. (198).

\subsection{Dopamine replacement therapies}

During the years of disease progression, the treatment of PD has to be adapted to alternating periods of reduced mobility and abnormal involuntary movements and is complicated by the onset of motor fluctuations and dyskinesia (199). PD was essentially an untreated motor disorder before L-DOPA was developed as a treatment. For the next two decades, the symptoms of hallucinations and delirium or other motor complications and psychiatric manifestations became the prevailing clinical problems in PD after treatment with L-DOPA. However, bradykinesia, resting tremors and rigidity which are the major symptoms of PD (200) can be controlled by long-term use of L-DOPA and other dopaminergic agents. Although the dopamine precursor, L-DOPA, and dopamine agonists are very effective in treating motor symptoms, they can cause substantial motor and behavioural adverse effects. Many reports have claimed that some patients treated with dopaminergic drugs develop 
impulse control disorders, a dopamine dysregulation syndrome or other abnormal behaviors (201). Because of these flaws, new treatments for PD should be developed to tackle two unresolved problems: the alternation between therapies that alleviate symptoms and those that modify the disease; and reduction of the real causes of disability in long-term PD, which include autonomic dysfunction, balance loss, cognitive impairment and the growing prevalence of other non-motor symptoms.

Peak-dose dyskinesia, diphasic dyskinesia and off-period dystonia are the three forms of dyskinesias that commonly occur with L-DOPA use and negatively affect the quality of life of patients in the advanced stages of the disease (202). Peak-dose dyskinesia occurs when plasma L-DOPA levels are highest; diphasic dyskinesia refers to the abnormal involuntary movements that occur transiently at the onset and end of L-DOPA efficacy; and off-period dystonia occurs when a patient receives subtherapeutic levels of L-DOPA. Recent advances in the treatment of severe disabling dyskinesias have lessened but not entirely eliminated their effects. Specific examples of such advances include deep brain stimulation (DBS) of the subthalamic nucleus, continuous subcutaneous infusion of apomorphine and continuous duodenal infusion of L-DOPA. Currently, a major focus of drug development is the identification of agents that can acutely suppress existing disabling dyskinesias and of agents that do not induce dyskinesias.

More than $80 \%$ of patients who have had PD for 20 years develop dementia. Once this occurs, irrespective of their age or the duration of the disease, death follows shortly (203). From an anatomopathological point of view, PD dementia is believed to be due to a combination of the extension of Lewy bodies into limbic and cortical structures with concomitant Alzheimer's disease(AD)-related neurofibrillary tangles and amyloid- $\beta$ plaque pathology (203-204). The recent observation that lower levels of amyloid- $\beta_{1-42}$ in the cerebral spinal fluid may predict a more rapid cognitive decline supports the contribution of AD-related pathologies to the cognitive impairment that is seen in patients with PD (205). Relief from neuropsychiatric cognitive and behavioral symptoms without worsening motor impairment or altering the relief of symptoms that is provided by L-DOPA are the goals of current treatment in PD dementia. To achieve these goals, reliance is placed on fine-tuning the balance between dopaminergic and non-dopaminergic (prominently cholinergic) neurotransmission strategies.

\subsection{Surgical treatment and deep brain stimulation (DBS)}

In recent years, DBS has become an established treatment for the advanced stages of PD. It is efficacious and is approved by the US Food and Drug Administration for the treatment of advanced, L-DOPA-responsive PD and medically refractory essential tremor. New anatomical targets for DBS, such as the pedunculopontine nucleus, are currently being explored in patients with PD who have gait disorders. In the search for new targets, smart DBS techniques such as coordinated reset stimulation are currently under development (206).

Many reports have enlarged described the long-term outcome of DBS in PD, but, as with LDOPS treatment, flaws still remain. Subthalamic nucleus DBS (STN DBS) can substantially improve motor function and quality of life in some patients with PD; however, a minority of patients experience cognitive and emotional difficulties after surgery. Better controlled 
randomized trials that compared STN DBS with the best medical therapy failed to substantiate the findings of widespread or marked cognitive deterioration (207-208).

Smeding and colleagues (209) reported on predictors of the cognitive and psychosocial effects of STN DBS in patients with PD. Varied mood outcomes were observed: 16 patients treated with STN DBS (15\%) showed improvements, but the same percentage showed deterioration. Strutt and colleagues (210) have shown that mood (depression) changes cannot be attributed solely to symptoms of somatic depression that overlap with those of PD.

The pre-operative selection of patients who are suitable for STN DBS is critical; response to L-DOPA is considered to be not only a predictor of motor outcomes, but perhaps also of neurocognitive and quality of life outcomes. As pre-operative impairments can predict neuropsychological outcomes after therapy, neuropsychological evaluation should be undertaken before surgery. Mood states should also be evaluated, but reliance on selfreported questionnaires should be discouraged (211).

Although aging is suggested to be a prognostic factor of neurosurgical outcome (212-213), studies that trace the long-term clinical evolution among subgroups of patients with earlyonset versus late-onset PD after STN DBS are still lacking. The latest study of a cohort of 19 subjects treated with subthalamic nucleus DBS after more than 20 years of disease reported clinical and neuropsychological data up to a mean of 30 years after disease onset (214). A higher prevalence of axial and non-L-DOPA-responsive symptoms was observed during long-term evaluations compared with other STN DBS follow-up studies. This confirms that, even in patients with an early onset of disease and a previous long-lasting response to dopaminergic therapies, several complex aspects underlie the development of non-motor symptoms and other features of the progression of PD. Therefore, the surgical option of STN DBS should be proposed earlier, since the progression of PD might not follow a single direction, and it is possible that age might affect the development of non-motor features more than the duration of the disease.

\subsection{Transplantation treatment}

Pharmacological agents that increase DA can alleviate motor symptoms as mentioned above; however, patients develop severe effects with long-term use. Cell transplantation therapy has therefore been investigated as an alternative treatment in recent years. Since only one cell type is affected in a distinct location of the brain, cell replacement therapy is liable to be successful for PD, and has already been used in many other diseases. Transplantation treatment is considered to be an on-going alternative strategy for an effective cure for PD.

Stem-cell replacement therapy has been suggested as a treatment for neurodegenerative diseases caused by the degeneration of DA neurons in the substantia nigra of the brain, and especially for PD (215). Stem cell-derived DA neurons can replace endogenous degenerated neurons. Clinical studies using fetal midbrain tissue proved the principle that cell transplantation could be a feasible treatment for $\operatorname{PD}(216)$.

Although it has shown promise for the treatment of PD, the safety and efficacy of transplanted stem cells induced by different methods are variable. Fetal-tissue transplants 
have gained some success, but their availability is limited. Human induced pluripotent stem cells (hiPSCs) are a promising alternative for personalized therapy; many cells can be generated and the chances of immunorejection are low. Several reprograming methods can generate hiPSCs, the most common of which are lentiviral and retroviral methods, but these can generate mutations and lead to chromosomal aberrations.

Recently, Rhee and colleagues (217) compared the safety of several types of hiPSCs, and found that they were able to generate healthy DA neurons. Neural precursor cells from protein-based hiPSCs were transplanted into a rat model of PD. The transplanted tissue not only survived well but also was able to rescue motor deficits in the model animals. These findings suggest that protein-based hiPSCs can be considered as a safe, viable alternative to virus-induced cells; moreover, they could potentially be used for transplantation and treatment in patients with PD (218).

\subsection{Neuroprotective effects}

DA substitution therapy and DBS do not completely relieve the symptoms of PD. Hence, there is still a need to identify neuroprotective agents that can modify the progression of the underlying disease processes.

Due to its robust effects in preventing degeneration of the nigrostriatal system in commonly used neurotoxin-based pre-clinical models of the disease, glial cell line-derived neurotrophic factor (GDNF) has gained most attention as a candidate neuroprotective molecule in PD. GDNF may be used in two ways to afford substantial neuroprotection in rodent and primate models of PD induced by either 6-OHDA or MPTP: infusion and viral-mediated delivery of GDNF, and transplantation of GDNF-producing cells (219-222).

Because of these promising pre-clinical results, more clinical trials to evaluate the efficacy of GDNF and neurturin in patients with PD are now in progress. However, the results obtained from these trials to date remain inconclusive (223-225).

Another recent study demonstrated that viral vector-mediated delivery of GDNF is unable to prevent the degeneration of the nigrostriatal DA neurons induced by over-expression of human wild-type a-synuclein at levels that have been shown to be efficient in the toxin models; this highlights the importance of performing pre-clinical tests on potential therapeutic compounds in mechanistically different models of PD (226).

\section{Conclusions}

As is the case for many other diseases that humans have been fighting for decades, there is a common gap between laboratory research and the ideal clinical therapy: how to ensure that products derived from laboratory experiments are both efficacious and safe. Although various studies have made progress towards a definitive solution for PD, several unresolved areas still remain. A better understanding of its biochemical pathogenesis is the best method to develop new disease-modifying therapies. However, through novel therapies and the refinement of old treatments, the management of this disease has been considerably upgraded over the past 20 years. Clinical experience shows that most patients who have accepted treatment now have a relatively good quality of life despite having suffered the effects of PD for many years. We should be confident that all these new developments will 
provide advances for PD treatment, and give us a hope of a final triumph in fighting the disease.

\section{References}

[1] Twelves D, Perkins KS, Counsell C. Systematic review of incidence studies of Parkinson's disease. Movement disorders : official journal of the Movement Disorder Society. 2003;18(1):19-31. doi: 10.1002/mds.10305.

[2] Bower JH, Maraganore DM, McDonnell SK, Rocca WA. Incidence and distribution of parkinsonism in Olmsted County, Minnesota, 1976-1990. Neurology. 1999;52(6):1214-20.

[3] Elbaz A, Bower JH, Maraganore DM, McDonnell SK, Peterson BJ, Ahlskog JE, et al. Risk tables for parkinsonism and Parkinson's disease. Journal of clinical epidemiology. 2002;55(1):25-31.

[4] Zhang ZX, Roman GC, Hong Z, Wu CB, Qu QM, Huang JB, et al. Parkinson's disease in China: prevalence in Beijing, Xian, and Shanghai. Lancet. 2005;365(9459):595-7. doi: 10.1016/S0140-6736(05)17909-4.

[5] Schoenberg BS, Osuntokun BO, Adeuja AO, Bademosi O, Nottidge V, Anderson DW, et al. Comparison of the prevalence of Parkinson's disease in black populations in the rural United States and in rural Nigeria: door-to-door community studies. Neurology. 1988;38(4):645-6.

[6] Priyadarshi A, Khuder SA, Schaub EA, Priyadarshi SS. Environmental risk factors and Parkinson's disease: a metaanalysis. Environmental research. 2001;86(2):122-7. doi: 10.1006/enrs.2001.4264.

[7] Priyadarshi A, Khuder SA, Schaub EA, Shrivastava S. A meta-analysis of Parkinson's disease and exposure to pesticides. Neurotoxicology. 2000;21(4):435-40.

[8] Migliore L, Coppede F. Genetics, environmental factors and the emerging role of epigenetics in neurodegenerative diseases. Mutation research. 2009;667(1-2):82-97. doi: 10.1016/j.mrfmmm.2008.10.011.

[9] Tanner CM, Goldman SM. Epidemiology of Parkinson's disease. Neurologic clinics. 1996;14(2):317-35.

[10] Barbeau A, Roy M, Bernier G, Campanella G, Paris S. Ecogenetics of Parkinson's disease: prevalence and environmental aspects in rural areas. The Canadian journal of neurological sciences Le journal canadien des sciences neurologiques. 1987;14(1):36-41.

[11] Gorrell JM, DiMonte D, Graham D. The role of the environment in Parkinson's disease. Environmental health perspectives. 1996;104(6):652-4.

[12] Gorell JM, Johnson CC, Rybicki BA, Peterson EL, Richardson RJ. The risk of Parkinson's disease with exposure to pesticides, farming, well water, and rural living. Neurology. 1998;50(5):1346-50.

[13] Semchuk KM, Love EJ, Lee RG. Parkinson's disease and exposure to agricultural work and pesticide chemicals. Neurology. 1992;42(7):1328-35.

[14] Langston JW, Ballard P, Tetrud JW, Irwin I. Chronic Parkinsonism in humans due to a product of meperidine-analog synthesis. Science. 1983;219(4587):979-80.

[15] Langston JW. The etiology of Parkinson's disease with emphasis on the MPTP story. Neurology. 1996;47(6 Suppl 3):S153-60. 
[16] Liou HH, Tsai MC, Chen CJ, Jeng JS, Chang YC, Chen SY, et al. Environmental risk factors and Parkinson's disease: a case-control study in Taiwan. Neurology. 1997;48(6):1583-8.

[17] Seidler A, Hellenbrand W, Robra BP, Vieregge P, Nischan P, Joerg J, et al. Possible environmental, occupational, and other etiologic factors for Parkinson's disease: a case-control study in Germany. Neurology. 1996;46(5):1275-84.

[18] Corsini GU, Pintus S, Chiueh CC, Weiss JF, Kopin IJ. 1-Methyl-4-phenyl-1,2,3,6tetrahydropyridine (MPTP) neurotoxicity in mice is enhanced by pretreatment with diethyldithiocarbamate. European journal of pharmacology. 1985;119(1-2):127-8.

[19] Semchuk KM, Love EJ, Lee RG. Parkinson's disease and exposure to rural environmental factors: a population based case-control study. The Canadian journal of neurological sciences Le journal canadien des sciences neurologiques. 1991;18(3):279-86.

[20] Huang CC, Lu CS, Chu NS, Hochberg F, Lilienfeld D, Olanow W, et al. Progression after chronic manganese exposure. Neurology. 1993;43(8):1479-83.

[21] Costello S, Cockburn M, Bronstein J, Zhang X, Ritz B. Parkinson's disease and residential exposure to maneb and paraquat from agricultural applications in the central valley of California. American journal of epidemiology. 2009;169(8):919-26. doi: 10.1093/aje/kwp006.

[22] Gorell JM, Johnson CC, Rybicki BA, Peterson EL, Kortsha GX, Brown GG, et al. Occupational exposures to metals as risk factors for Parkinson's disease. Neurology. 1997;48(3):650-8.

[23] Rybicki BA, Johnson CC, Uman J, Gorell JM. Parkinson's disease mortality and the industrial use of heavy metals in Michigan. Movement disorders : official journal of the Movement Disorder Society. 1993;8(1):87-92. doi: 10.1002/mds.870080116.

[24] Maher NE, Golbe LI, Lazzarini AM, Mark MH, Currie LJ, Wooten GF, et al. Epidemiologic study of 203 sibling pairs with Parkinson's disease: the GenePD study. Neurology. 2002;58(1):79-84.

[25] Goldman SM, Tanner CM, Oakes D, Bhudhikanok GS, Gupta A, Langston JW. Head injury and Parkinson's disease risk in twins. Annals of neurology. 2006;60(1):65-72. doi: 10.1002/ana.20882.

[26] Baron JA. Cigarette smoking and Parkinson's disease. Neurology. 1986;36(11):1490-6.

[27] Ascherio A, Zhang SM, Hernan MA, Kawachi I, Colditz GA, Speizer FE, et al. Prospective study of caffeine consumption and risk of Parkinson's disease in men and women. Annals of neurology. 2001;50(1):56-63.

[28] Wirdefeldt K, Gatz M, Pawitan Y, Pedersen NL. Risk and protective factors for Parkinson's disease: a study in Swedish twins. Annals of neurology. 2005;57(1):2733. doi: 10.1002/ana.20307.

[29] Tanner CM, Goldman SM, Aston DA, Ottman R, Ellenberg J, Mayeux R, et al. Smoking and Parkinson's disease in twins. Neurology. 2002;58(4):581-8.

[30] Scott WK, Zhang F, Stajich JM, Scott BL, Stacy MA, Vance JM. Family-based case-control study of cigarette smoking and Parkinson disease. Neurology. 2005;64(3):442-7. doi: 10.1212/01.WNL.0000150905.93241.B2.

[31] Hernan MA, Takkouche B, Caamano-Isorna F, Gestal-Otero JJ. A meta-analysis of coffee drinking, cigarette smoking, and the risk of Parkinson's disease. Annals of neurology. 2002;52(3):276-84. doi: 10.1002/ana.10277. 
[32] Elbaz A, McDonnell SK, Maraganore DM, Strain KJ, Schaid DJ, Bower JH, et al. Validity of family history data on PD: evidence for a family information bias. Neurology. 2003;61(1):11-7.

[33] Farrer MJ. Genetics of Parkinson disease: paradigm shifts and future prospects. Nature reviews Genetics. 2006;7(4):306-18. doi: 10.1038/nrg1831.

[34] Polymeropoulos MH, Higgins JJ, Golbe LI, Johnson WG, Ide SE, Di Iorio G, et al. Mapping of a gene for Parkinson's disease to chromosome 4q21-q23. Science. 1996;274(5290):1197-9.

[35] Polymeropoulos MH, Lavedan C, Leroy E, Ide SE, Dehejia A, Dutra A, et al. Mutation in the alpha-synuclein gene identified in families with Parkinson's disease. Science. 1997;276(5321):2045-7.

[36] Kruger R, Kuhn W, Muller T, Woitalla D, Graeber M, Kosel S, et al. Ala30Pro mutation in the gene encoding alpha-synuclein in Parkinson's disease. Nature genetics. 1998;18(2):106-8. doi: 10.1038/ng0298-106.

[37] Zarranz JJ, Alegre J, Gomez-Esteban JC, Lezcano E, Ros R, Ampuero I, et al. The new mutation, E46K, of alpha-synuclein causes Parkinson and Lewy body dementia. Annals of neurology. 2004;55(2):164-73. doi: 10.1002/ana.10795.

[38] Farrer M, Kachergus J, Forno L, Lincoln S, Wang DS, Hulihan M, et al. Comparison of kindreds with parkinsonism and alpha-synuclein genomic multiplications. Annals of neurology. 2004;55(2):174-9. doi: 10.1002/ana.10846.

[39] Lockhart PJ, Kachergus J, Lincoln S, Hulihan M, Bisceglio G, Thomas N, et al. Multiplication of the alpha-synuclein gene is not a common disease mechanism in Lewy body disease. Journal of molecular neuroscience : MN. 2004;24(3):337-42. doi: 10.1385/JMN:24:3:337.

[40] Fuchs J, Nilsson C, Kachergus J, Munz M, Larsson EM, Schule B, et al. Phenotypic variation in a large Swedish pedigree due to SNCA duplication and triplication. Neurology. 2007;68(12):916-22. doi: 10.1212/01.wnl.0000254458.17630.c5.

[41] Spillantini MG, Schmidt ML, Lee VM, Trojanowski JQ, Jakes R, Goedert M. Alphasynuclein in Lewy bodies. Nature. 1997;388(6645):839-40. doi: 10.1038/42166.

[42] Spillantini MG, Crowther RA, Jakes R, Hasegawa M, Goedert M. alpha-Synuclein in filamentous inclusions of Lewy bodies from Parkinson's disease and dementia with lewy bodies. Proceedings of the National Academy of Sciences of the United States of America. 1998;95(11):6469-73.

[43] Kitada T, Asakawa S, Hattori N, Matsumine H, Yamamura Y, Minoshima S, et al. Mutations in the parkin gene cause autosomal recessive juvenile parkinsonism. Nature. 1998;392(6676):605-8. doi: 10.1038/33416.

[44] Takahashi H, Ohama E, Suzuki S, Horikawa Y, Ishikawa A, Morita T, et al. Familial juvenile parkinsonism: clinical and pathologic study in a family. Neurology. 1994;44(3 Pt 1):437-41.

[45] Ishikawa A, Tsuji S. Clinical analysis of 17 patients in 12 Japanese families with autosomal-recessive type juvenile parkinsonism. Neurology. 1996;47(1):160-6.

[46] Shimura H, Hattori N, Kubo S, Mizuno Y, Asakawa S, Minoshima S, et al. Familial Parkinson disease gene product, parkin, is a ubiquitin-protein ligase. Nature genetics. 2000;25(3):302-5. doi: 10.1038/77060.

[47] Fallon L, Belanger CM, Corera AT, Kontogiannea M, Regan-Klapisz E, Moreau F, et al. A regulated interaction with the UIM protein Eps15 implicates parkin in EGF 
receptor trafficking and PI(3)K-Akt signalling. Nature cell biology. 2006;8(8):834-42. doi: $10.1038 /$ ncb1441.

[48] Mata IF, Lockhart PJ, Farrer MJ. Parkin genetics: one model for Parkinson's disease. Human molecular genetics. 2004;13 Spec No 1:R127-33. doi: 10.1093/hmg/ddh089.

[49] Lesage S, Magali P, Lohmann E, Lacomblez L, Teive H, Janin S, et al. Deletion of the parkin and PACRG gene promoter in early-onset parkinsonism. Human mutation. 2007;28(1):27-32. doi: 10.1002/humu.20436.

[50] Lucking CB, Durr A, Bonifati V, Vaughan J, De Michele G, Gasser T, et al. Association between early-onset Parkinson's disease and mutations in the parkin gene. The New England journal of medicine. 2000;342(21):1560-7. doi: 10.1056/NEJM200005253422103.

[51] Periquet M, Latouche M, Lohmann E, Rawal N, De Michele G, Ricard S, et al. Parkin mutations are frequent in patients with isolated early-onset parkinsonism. Brain : a journal of neurology. 2003;126(Pt 6):1271-8.

[52] Leroy E, Boyer R, Auburger G, Leube B, Ulm G, Mezey E, et al. The ubiquitin pathway in Parkinson's disease. Nature. 1998;395(6701):451-2. doi: 10.1038/26652.

[53] Farrer M, Destee T, Becquet E, Wavrant-De Vrieze F, Mouroux V, Richard F, et al. Linkage exclusion in French families with probable Parkinson' s disease. Movement disorders : official journal of the Movement Disorder Society. 2000;15(6):1075-83.

[54] Harhangi BS, Farrer MJ, Lincoln S, Bonifati V, Meco G, De Michele G, et al. The Ile93Met mutation in the ubiquitin carboxy-terminal-hydrolase-L1 gene is not observed in European cases with familial Parkinson's disease. Neuroscience letters. 1999;270(1):1-4.

[55] Lincoln S, Vaughan J, Wood N, Baker M, Adamson J, Gwinn-Hardy K, et al. Low frequency of pathogenic mutations in the ubiquitin carboxy-terminal hydrolase gene in familial Parkinson's disease. Neuroreport. 1999;10(2):427-9.

[56] Valente EM, Abou-Sleiman PM, Caputo V, Muqit MM, Harvey K, Gispert S, et al. Hereditary early-onset Parkinson's disease caused by mutations in PINK1. Science. 2004;304(5674):1158-60. doi: 10.1126/science.1096284.

[57] Valente EM, Salvi S, Ialongo T, Marongiu R, Elia AE, Caputo V, et al. PINK1 mutations are associated with sporadic early-onset parkinsonism. Annals of neurology. 2004;56(3):336-41. doi: 10.1002/ana.20256.

[58] Marongiu R, Brancati F, Antonini A, Ialongo T, Ceccarini C, Scarciolla O, et al. Whole gene deletion and splicing mutations expand the PINK1 genotypic spectrum. Human mutation. 2007;28(1):98. doi: 10.1002/humu.9472.

[59] Abou-Sleiman PM, Muqit MM, McDonald NQ, Yang YX, Gandhi S, Healy DG, et al. A heterozygous effect for PINK1 mutations in Parkinson's disease? Annals of neurology. 2006;60(4):414-9. doi: 10.1002/ana.20960.

[60] Sim CH, Lio DS, Mok SS, Masters CL, Hill AF, Culvenor JG, et al. C-terminal truncation and Parkinson's disease-associated mutations down-regulate the protein serine/threonine kinase activity of PTEN-induced kinase-1. Human molecular genetics. 2006;15(21):3251-62. doi: 10.1093/hmg/ddl398.

[61] Bonifati V, Rizzu P, van Baren MJ, Schaap O, Breedveld GJ, Krieger E, et al. Mutations in the DJ-1 gene associated with autosomal recessive early-onset parkinsonism. Science. 2003;299(5604):256-9. doi: 10.1126/science.1077209. 
[62] Pankratz N, Pauciulo MW, Elsaesser VE, Marek DK, Halter CA, Wojcieszek J, et al. Mutations in DJ-1 are rare in familial Parkinson disease. Neuroscience letters. 2006;408(3):209-13. doi: 10.1016/j.neulet.2006.09.003.

[63] Miller DW, Ahmad R, Hague S, Baptista MJ, Canet-Aviles R, McLendon C, et al. L166P mutant DJ-1, causative for recessive Parkinson's disease, is degraded through the ubiquitin-proteasome system. The Journal of biological chemistry. 2003;278(38):36588-95. doi: 10.1074/jbc.M304272200.

[64] Di Fonzo A, Rohe CF, Ferreira J, Chien HF, Vacca L, Stocchi F, et al. A frequent LRRK2 gene mutation associated with autosomal dominant Parkinson's disease. Lancet. 2005;365(9457):412-5. doi: 10.1016/S0140-6736(05)17829-5.

[65] Nichols WC, Pankratz N, Hernandez D, Paisan-Ruiz C, Jain S, Halter CA, et al. Genetic screening for a single common LRRK2 mutation in familial Parkinson's disease. Lancet. 2005;365(9457):410-2. doi: 10.1016/S0140-6736(05)17828-3.

[66] Gilks WP, Abou-Sleiman PM, Gandhi S, Jain S, Singleton A, Lees AJ, et al. A common LRRK2 mutation in idiopathic Parkinson's disease. Lancet. 2005;365(9457):415-6. doi: 10.1016/S0140-6736(05)17830-1.

[67] Zabetian CP, Samii A, Mosley AD, Roberts JW, Leis BC, Yearout D, et al. A clinic-based study of the LRRK2 gene in Parkinson disease yields new mutations. Neurology. 2005;65(5):741-4. doi: 10.1212/01.wnl.0000172630.22804.73.

[68] Kachergus J, Mata IF, Hulihan M, Taylor JP, Lincoln S, Aasly J, et al. Identification of a novel LRRK2 mutation linked to autosomal dominant parkinsonism: evidence of a common founder across European populations. American journal of human genetics. 2005;76(4):672-80. doi: 10.1086/429256.

[69] Hampshire DJ, Roberts E, Crow Y, Bond J, Mubaidin A, Wriekat AL, et al. Kufor-Rakeb syndrome, pallido-pyramidal degeneration with supranuclear upgaze paresis and dementia, maps to 1p36. Journal of medical genetics. 2001;38(10):680-2.

[70] Ramirez A, Heimbach A, Grundemann J, Stiller B, Hampshire D, Cid LP, et al. Hereditary parkinsonism with dementia is caused by mutations in ATP13A2, encoding a lysosomal type 5 P-type ATPase. Nature genetics. 2006;38(10):1184-91. doi: $10.1038 /$ ng1884.

[71] Di Fonzo A, Chien HF, Socal M, Giraudo S, Tassorelli C, Iliceto G, et al. ATP13A2 missense mutations in juvenile parkinsonism and young onset Parkinson disease. Neurology. 2007;68(19):1557-62. doi: 10.1212/01.wnl.0000260963.08711.08.

[72] Strauss KM, Martins LM, Plun-Favreau H, Marx FP, Kautzmann S, Berg D, et al. Loss of function mutations in the gene encoding Omi/HtrA2 in Parkinson's disease. Human molecular genetics. 2005;14(15):2099-111. doi: 10.1093/hmg/ddi215.

[73] Sidransky E, Nalls MA, Aasly JO, Aharon-Peretz J, Annesi G, Barbosa ER, et al. Multicenter analysis of glucocerebrosidase mutations in Parkinson's disease. The New England journal of medicine. 2009;361(17):1651-61. doi: 10.1056/NEJMoa0901281.

[74] Zabetian CP, Hutter CM, Factor SA, Nutt JG, Higgins DS, Griffith A, et al. Association analysis of MAPT H1 haplotype and subhaplotypes in Parkinson's disease. Annals of neurology. 2007;62(2):137-44. doi: 10.1002/ana.21157.

[75] Baker M, Mackenzie IR, Pickering-Brown SM, Gass J, Rademakers R, Lindholm C, et al. Mutations in progranulin cause tau-negative frontotemporal dementia linked to chromosome 17. Nature. 2006;442(7105):916-9. doi: 10.1038/nature05016. 
[76] Schober A. Classic toxin-induced animal models of Parkinson's disease: 6-OHDA and MPTP. Cell and tissue research. 2004;318(1):215-24. doi: 10.1007/s00441-004-0938-y.

[77] Ungerstedt U. Postsynaptic supersensitivity after 6-hydroxy-dopamine induced degeneration of the nigro-striatal dopamine system. Acta physiologica Scandinavica Supplementum. 1971;367:69-93.

[78] Saner A, Thoenen H. Model experiments on the molecular mechanism of action of 6hydroxydopamine. Molecular pharmacology. 1971;7(2):147-54.

[79] Cohen G. Oxy-radical toxicity in catecholamine neurons. Neurotoxicology. 1984;5(1):7782.

[80] Rodriguez Diaz M, Abdala P, Barroso-Chinea P, Obeso J, Gonzalez-Hernandez T. Motor behavioural changes after intracerebroventricular injection of 6-hydroxydopamine in the rat: an animal model of Parkinson's disease. Behavioural brain research. 2001;122(1):79-92.

[81] Zigmond MJ, Stricker EM. Recovery of feeding and drinking by rats after intraventricular 6-hydroxydopamine or lateral hypothalamic lesions. Science. 1973;182(113):717-20.

[82] Sauer H, Oertel WH. Progressive degeneration of nigrostriatal dopamine neurons following intrastriatal terminal lesions with 6-hydroxydopamine: a combined retrograde tracing and immunocytochemical study in the rat. Neuroscience. 1994;59(2):401-15.

[83] Marti MJ, James CJ, Oo TF, Kelly WJ, Burke RE. Early developmental destruction of terminals in the striatal target induces apoptosis in dopamine neurons of the substantia nigra. The Journal of neuroscience : the official journal of the Society for Neuroscience. 1997;17(6):2030-9.

[84] Marti MJ, Saura J, Burke RE, Jackson-Lewis V, Jimenez A, Bonastre M, et al. Striatal 6hydroxydopamine induces apoptosis of nigral neurons in the adult rat. Brain research. 2002;958(1):185-91.

[85] Jeon BS, Jackson-Lewis V, Burke RE. 6-Hydroxydopamine lesion of the rat substantia nigra: time course and morphology of cell death. Neurodegeneration : a journal for neurodegenerative disorders, neuroprotection, and neuroregeneration. 1995;4(2):131-7.

[86] Bove J, Prou D, Perier C, Przedborski S. Toxin-induced models of Parkinson's disease. NeuroRx : the journal of the American Society for Experimental NeuroTherapeutics. 2005;2(3):484-94.

[87] Falkenburger BH, Schulz JB. Limitations of cellular models in Parkinson's disease research. Journal of neural transmission Supplementum. 2006;(70):261-8.

[88] Terzioglu M, Galter D. Parkinson's disease: genetic versus toxin-induced rodent models. The FEBS journal. 2008;275(7):1384-91. doi: 10.1111/j.1742-4658.2008.06302.x.

[89] Hisahara S, Shimohama S. Toxin-induced and genetic animal models of Parkinson's disease. Parkinson's disease. 2010;2011:951709. doi: 10.4061/2011/951709.

[90] Dawson T, Mandir A, Lee M. Animal models of PD: pieces of the same puzzle? Neuron. 2002;35(2):219-22.

[91] Bezard E, Gross CE, Fournier MC, Dovero S, Bloch B, Jaber M. Absence of MPTPinduced neuronal death in mice lacking the dopamine transporter. Experimental neurology. 1999;155(2):268-73. doi: 10.1006/exnr.1998.6995. 
[92] Ramsay RR, Singer TP. Energy-dependent uptake of N-methyl-4-phenylpyridinium, the neurotoxic metabolite of 1-methyl-4-phenyl-1,2,3,6-tetrahydropyridine, by mitochondria. The Journal of biological chemistry. 1986;261(17):7585-7.

[93] Langston JW, Forno LS, Tetrud J, Reeves AG, Kaplan JA, Karluk D. Evidence of active nerve cell degeneration in the substantia nigra of humans years after 1-methyl-4phenyl-1,2,3,6-tetrahydropyridine exposure. Annals of neurology. 1999;46(4):598605.

[94] Forno LS, DeLanney LE, Irwin I, Langston JW. Similarities and differences between MPTP-induced parkinsonsim and Parkinson's disease. Neuropathologic considerations. Advances in neurology. 1993;60:600-8.

[95] Sonsalla PK, Heikkila RE. The influence of dose and dosing interval on MPTP-induced dopaminergic neurotoxicity in mice. European journal of pharmacology. 1986;129(3):339-45.

[96] Ricaurte GA, Langston JW, Delanney LE, Irwin I, Peroutka SJ, Forno LS. Fate of nigrostriatal neurons in young mature mice given 1-methyl-4-phenyl-1,2,3,6tetrahydropyridine: a neurochemical and morphological reassessment. Brain research. 1986;376(1):117-24.

[97] Schneider JS, Denaro FJ. Astrocytic responses to the dopaminergic neurotoxin 1-methyl4-phenyl-1,2,3,6-tetrahydropyridine (MPTP) in cat and mouse brain. Journal of neuropathology and experimental neurology. 1988;47(4):452-8.

[98] Jackson-Lewis V, Jakowec M, Burke RE, Przedborski S. Time course and morphology of dopaminergic neuronal death caused by the neurotoxin 1-methyl-4-phenyl-1,2,3,6tetrahydropyridine. Neurodegeneration : a journal for neurodegenerative disorders, neuroprotection, and neuroregeneration. 1995;4(3):257-69.

[99] Tatton NA, Kish SJ. In situ detection of apoptotic nuclei in the substantia nigra compacta of 1-methyl-4-phenyl-1,2,3,6-tetrahydropyridine-treated mice using terminal deoxynucleotidyl transferase labelling and acridine orange staining. Neuroscience. 1997;77(4):1037-48.

[100] Kurkowska-Jastrzebska I, Wronska A, Kohutnicka M, Czlonkowski A, Czlonkowska A. The inflammatory reaction following 1-methyl-4-phenyl-1,2,3, 6tetrahydropyridine intoxication in mouse. Experimental neurology. 1999;156(1):5061. doi: 10.1006/exnr.1998.6993.

[101] Furuya T, Hayakawa H, Yamada M, Yoshimi K, Hisahara S, Miura M, et al. Caspase-11 mediates inflammatory dopaminergic cell death in the 1-methyl-4-phenyl-1,2,3,6tetrahydropyridine mouse model of Parkinson's disease. The Journal of neuroscience : the official journal of the Society for Neuroscience. 2004;24(8):186572. doi: 10.1523/JNEUROSCI.3309-03.2004.

[102] Liberatore GT, Jackson-Lewis V, Vukosavic S, Mandir AS, Vila M, McAuliffe WG, et al. Inducible nitric oxide synthase stimulates dopaminergic neurodegeneration in the MPTP model of Parkinson disease. Nature medicine. 1999;5(12):1403-9. doi: $10.1038 / 70978$.

[103] Wade TV, Schneider JS. Expression of striatal preprotachykinin mRNA in symptomatic and asymptomatic 1-methyl-4-phenyl-1,2,3,6-tetrahydropyridine-exposed monkeys is related to parkinsonian motor signs. The Journal of neuroscience : the official journal of the Society for Neuroscience. 2001;21(13):4901-7. 
[104] Bloem BR, Irwin I, Buruma OJ, Haan J, Roos RA, Tetrud JW, et al. The MPTP model: versatile contributions to the treatment of idiopathic Parkinson's disease. Journal of the neurological sciences. 1990;97(2-3):273-93.

[105] Zigmond MJ, Stricker EM. Animal models of parkinsonism using selective neurotoxins: clinical and basic implications. International review of neurobiology. 1989;31:1-79.

[106] Kopin IJ. MPTP: an industrial chemical and contaminant of illicit narcotics stimulates a new era in research on Parkinson's disease. Environmental health perspectives. 1987;75:45-51.

[107] Kitamura Y, Kakimura J, Taniguchi T. Protective effect of talipexole on MPTP-treated planarian, a unique parkinsonian worm model. Japanese journal of pharmacology. 1998;78(1):23-9.

[108] Giovanni A, Sieber BA, Heikkila RE, Sonsalla PK. Studies on species sensitivity to the dopaminergic neurotoxin 1-methyl-4-phenyl-1,2,3,6-tetrahydropyridine. Part 1: Systemic administration. The Journal of pharmacology and experimental therapeutics. 1994;270(3):1000-7.

[109] Giovanni A, Sonsalla PK, Heikkila RE. Studies on species sensitivity to the dopaminergic neurotoxin 1-methyl-4-phenyl-1,2,3,6-tetrahydropyridine. Part 2: Central administration of 1-methyl-4-phenylpyridinium. The Journal of pharmacology and experimental therapeutics. 1994;270(3):1008-14.

[110] Przedborski S, Jackson-Lewis V, Naini AB, Jakowec M, Petzinger G, Miller R, et al. The parkinsonian toxin 1-methyl-4-phenyl-1,2,3,6-tetrahydropyridine (MPTP): a technical review of its utility and safety. Journal of neurochemistry. 2001;76(5):126574.

[111] Tolwani RJ, Jakowec MW, Petzinger GM, Green S, Waggie K. Experimental models of Parkinson's disease: insights from many models. Laboratory animal science. 1999;49(4):363-71.

[112] Sedelis M, Hofele K, Auburger GW, Morgan S, Huston JP, Schwarting RK. MPTP susceptibility in the mouse: behavioral, neurochemical, and histological analysis of gender and strain differences. Behavior genetics. 2000;30(3):171-82.

[113] Jenner P. The contribution of the MPTP-treated primate model to the development of new treatment strategies for Parkinson's disease. Parkinsonism \& related disorders. 2003;9(3):131-7.

[114] Betarbet R, Sherer TB, MacKenzie G, Garcia-Osuna M, Panov AV, Greenamyre JT. Chronic systemic pesticide exposure reproduces features of Parkinson's disease. Nature neuroscience. 2000;3(12):1301-6. doi: 10.1038/81834.

[115] Schuler F, Casida JE. Functional coupling of PSST and ND1 subunits in NADH:ubiquinone oxidoreductase established by photoaffinity labeling. Biochimica et biophysica acta. 2001;1506(1):79-87.

[116] Marshall LE, Himes RH. Rotenone inhibition of tubulin self-assembly. Biochimica et biophysica acta. 1978;543(4):590-4.

[117] Burke D, Gasdaska P, Hartwell L. Dominant effects of tubulin overexpression in Saccharomyces cerevisiae. Molecular and cellular biology. 1989;9(3):1049-59.

[118] Sherer TB, Betarbet R, Testa CM, Seo BB, Richardson JR, Kim JH, et al. Mechanism of toxicity in rotenone models of Parkinson's disease. The Journal of neuroscience : the official journal of the Society for Neuroscience. 2003;23(34):10756-64. 
[119] Uversky VN. Neurotoxicant-induced animal models of Parkinson's disease: understanding the role of rotenone, maneb and paraquat in neurodegeneration. Cell and tissue research. 2004;318(1):225-41. doi: 10.1007/s00441-004-0937-z.

[120] Sherer TB, Betarbet R, Kim JH, Greenamyre JT. Selective microglial activation in the rat rotenone model of Parkinson's disease. Neuroscience letters. 2003;341(2):87-90.

[121] Sherer TB, Kim JH, Betarbet R, Greenamyre JT. Subcutaneous rotenone exposure causes highly selective dopaminergic degeneration and alpha-synuclein aggregation. Experimental neurology. 2003;179(1):9-16.

[122] Betarbet R, Canet-Aviles RM, Sherer TB, Mastroberardino PG, McLendon C, Kim JH, et al. Intersecting pathways to neurodegeneration in Parkinson's disease: effects of the pesticide rotenone on DJ-1, alpha-synuclein, and the ubiquitin-proteasome system. Neurobiology of disease. 2006;22(2):404-20. doi: 10.1016/j.nbd.2005.12.003.

[123] Klockgether T. Parkinson's disease: clinical aspects. Cell and tissue research. 2004;318(1):115-20. doi: 10.1007/s00441-004-0975-6.

[124] Alam M, Schmidt WJ. Rotenone destroys dopaminergic neurons and induces parkinsonian symptoms in rats. Behavioural brain research. 2002;136(1):317-24.

[125] Hely MA, Morris JG, Reid WG, Trafficante R. Sydney Multicenter Study of Parkinson's disease: non-L-dopa-responsive problems dominate at 15 years. Movement disorders : official journal of the Movement Disorder Society. 2005;20(2):190-9. doi: 10.1002/mds.20324.

[126] Greene JG, Noorian AR, Srinivasan S. Delayed gastric emptying and enteric nervous system dysfunction in the rotenone model of Parkinson's disease. Experimental neurology. 2009;218(1):154-61. doi: 10.1016/j.expneurol.2009.04.023.

[127] Drolet RE, Cannon JR, Montero L, Greenamyre JT. Chronic rotenone exposure reproduces Parkinson's disease gastrointestinal neuropathology. Neurobiology of disease. 2009;36(1):96-102. doi: 10.1016/j.nbd.2009.06.017.

[128] Di Monte D, Sandy MS, Ekstrom G, Smith MT. Comparative studies on the mechanisms of paraquat and 1-methyl-4-phenylpyridine (MPP+) cytotoxicity. Biochemical and biophysical research communications. 1986;137(1):303-9.

[129] Shimizu K, Matsubara K, Ohtaki K, Fujimaru S, Saito O, Shiono H. Paraquat induces long-lasting dopamine overflow through the excitotoxic pathway in the striatum of freely moving rats. Brain research. 2003;976(2):243-52.

[130] Brooks AI, Chadwick CA, Gelbard HA, Cory-Slechta DA, Federoff HJ. Paraquat elicited neurobehavioral syndrome caused by dopaminergic neuron loss. Brain research. 1999;823(1-2):1-10.

[131] Peng J, Mao XO, Stevenson FF, Hsu M, Andersen JK. The herbicide paraquat induces dopaminergic nigral apoptosis through sustained activation of the JNK pathway. The Journal of biological chemistry. 2004;279(31):32626-32. doi: 10.1074/jbc.M404596200.

[132] Purisai MG, McCormack AL, Cumine S, Li J, Isla MZ, Di Monte DA. Microglial activation as a priming event leading to paraquat-induced dopaminergic cell degeneration. Neurobiology of disease. 2007;25(2):392-400. doi: 10.1016/j.nbd.2006.10.008.

[133] Dringen R. Oxidative and antioxidative potential of brain microglial cells. Antioxidants \& redox signaling. 2005;7(9-10):1223-33. doi: 10.1089/ars.2005.7.1223. 
[134] Bonneh-Barkay D, Langston WJ, Di Monte DA. Toxicity of redox cycling pesticides in primary mesencephalic cultures. Antioxidants \& redox signaling. 2005;7(5-6):64953. doi: 10.1089 /ars.2005.7.649.

[135] Bonneh-Barkay D, Reaney SH, Langston WJ, Di Monte DA. Redox cycling of the herbicide paraquat in microglial cultures. Brain research Molecular brain research. 2005;134(1):52-6. doi: 10.1016/j.molbrainres.2004.11.005.

[136] McCormack AL, Atienza JG, Langston JW, Di Monte DA. Decreased susceptibility to oxidative stress underlies the resistance of specific dopaminergic cell populations to paraquat-induced degeneration. Neuroscience. 2006;141(2):929-37. doi: 10.1016/j.neuroscience.2006.03.069.

[137] Peng J, Stevenson FF, Doctrow SR, Andersen JK. Superoxide dismutase/catalase mimetics are neuroprotective against selective paraquat-mediated dopaminergic neuron death in the substantial nigra: implications for Parkinson disease. The Journal of biological chemistry. 2005;280(32):29194-8. doi: 10.1074/jbc.M500984200.

[138] Manning-Bog AB, McCormack AL, Li J, Uversky VN, Fink AL, Di Monte DA. The herbicide paraquat causes up-regulation and aggregation of alpha-synuclein in mice: paraquat and alpha-synuclein. The Journal of biological chemistry. 2002;277(3):1641-4. doi: 10.1074/jbc.C100560200.

[139] Thiruchelvam M, Brockel BJ, Richfield EK, Baggs RB, Cory-Slechta DA. Potentiated and preferential effects of combined paraquat and maneb on nigrostriatal dopamine systems: environmental risk factors for Parkinson's disease? Brain research. 2000;873(2):225-34.

[140] Zhang J, Fitsanakis VA, Gu G, Jing D, Ao M, Amarnath V, et al. Manganese ethylenebis-dithiocarbamate and selective dopaminergic neurodegeneration in rat: a link through mitochondrial dysfunction. Journal of neurochemistry. 2003;84(2):336-46.

[141] Thiruchelvam M, Richfield EK, Baggs RB, Tank AW, Cory-Slechta DA. The nigrostriatal dopaminergic system as a preferential target of repeated exposures to combined paraquat and maneb: implications for Parkinson's disease. The Journal of neuroscience : the official journal of the Society for Neuroscience. 2000;20(24):920714.

[142] Thiruchelvam M, McCormack A, Richfield EK, Baggs RB, Tank AW, Di Monte DA, et al. Age-related irreversible progressive nigrostriatal dopaminergic neurotoxicity in the paraquat and maneb model of the Parkinson's disease phenotype. The European journal of neuroscience. 2003;18(3):589-600.

[143] Barlow BK, Thiruchelvam MJ, Bennice L, Cory-Slechta DA, Ballatori N, Richfield EK. Increased synaptosomal dopamine content and brain concentration of paraquat produced by selective dithiocarbamates. Journal of neurochemistry. 2003;85(4):1075-86.

[144] Richfield EK, Thiruchelvam MJ, Cory-Slechta DA, Wuertzer C, Gainetdinov RR, Caron MG, et al. Behavioral and neurochemical effects of wild-type and mutated human alpha-synuclein in transgenic mice. Experimental neurology. 2002;175(1):35-48. doi: 10.1006/exnr.2002.7882.

[145] Thiruchelvam MJ, Powers JM, Cory-Slechta DA, Richfield EK. Risk factors for dopaminergic neuron loss in human alpha-synuclein transgenic mice. The European journal of neuroscience. 2004;19(4):845-54. 
[146] Masliah E, Rockenstein E, Veinbergs I, Mallory M, Hashimoto M, Takeda A, et al. Dopaminergic loss and inclusion body formation in alpha-synuclein mice: implications for neurodegenerative disorders. Science. 2000;287(5456):1265-9.

[147] Giasson BI, Duda JE, Quinn SM, Zhang B, Trojanowski JQ, Lee VM. Neuronal alphasynucleinopathy with severe movement disorder in mice expressing A53T human alpha-synuclein. Neuron. 2002;34(4):521-33.

[148] Lee MK, Stirling W, Xu Y, Xu X, Qui D, Mandir AS, et al. Human alpha-synucleinharboring familial Parkinson's disease-linked Ala-53 --> Thr mutation causes neurodegenerative disease with alpha-synuclein aggregation in transgenic mice. Proceedings of the National Academy of Sciences of the United States of America. 2002;99(13):8968-73. doi: 10.1073/pnas.132197599.

[149] Rockenstein E, Mallory M, Hashimoto M, Song D, Shults CW, Lang I, et al. Differential neuropathological alterations in transgenic mice expressing alpha-synuclein from the platelet-derived growth factor and Thy-1 promoters. Journal of neuroscience research. 2002;68(5):568-78. doi: 10.1002/jnr.10231.

[150] Song DD, Shults CW, Sisk A, Rockenstein E, Masliah E. Enhanced substantia nigra mitochondrial pathology in human alpha-synuclein transgenic mice after treatment with MPTP. Experimental neurology. 2004;186(2):158-72. doi: 10.1016/S00144886(03)00342-X.

[151] Martin LJ, Pan Y, Price AC, Sterling W, Copeland NG, Jenkins NA, et al. Parkinson's disease alpha-synuclein transgenic mice develop neuronal mitochondrial degeneration and cell death. The Journal of neuroscience : the official journal of the Society for Neuroscience. 2006;26(1):41-50. doi: 10.1523/JNEUROSCI.4308-05.2006.

[152] Kirik D, Rosenblad C, Burger C, Lundberg C, Johansen TE, Muzyczka N, et al. Parkinson-like neurodegeneration induced by targeted overexpression of alphasynuclein in the nigrostriatal system. The Journal of neuroscience : the official journal of the Society for Neuroscience. 2002;22(7):2780-91. doi: 20026246.

[153] Feany MB, Bender WW. A Drosophila model of Parkinson's disease. Nature. 2000;404(6776):394-8. doi: 10.1038/35006074.

[154] Lakso M, Vartiainen S, Moilanen AM, Sirvio J, Thomas JH, Nass R, et al. Dopaminergic neuronal loss and motor deficits in Caenorhabditis elegans overexpressing human alpha-synuclein. Journal of neurochemistry. 2003;86(1):165-72.

[155] Kuwahara T, Koyama A, Gengyo-Ando K, Masuda M, Kowa H, Tsunoda M, et al. Familial Parkinson mutant alpha-synuclein causes dopamine neuron dysfunction in transgenic Caenorhabditis elegans. The Journal of biological chemistry. 2006;281(1):334-40. doi: 10.1074/jbc.M504860200.

[156] Stefanis L, Kholodilov N, Rideout HJ, Burke RE, Greene LA. Synuclein-1 is selectively up-regulated in response to nerve growth factor treatment in PC12 cells. Journal of neurochemistry. 2001;76(4):1165-76.

[157] Clough RL, Stefanis L. A novel pathway for transcriptional regulation of alphasynuclein. The FASEB journal : official publication of the Federation of American Societies for Experimental Biology. 2007;21(2):596-607. doi: 10.1096/fj.06-7111com.

[158] Cuervo AM, Stefanis L, Fredenburg R, Lansbury PT, Sulzer D. Impaired degradation of mutant alpha-synuclein by chaperone-mediated autophagy. Science. 2004;305(5688):1292-5. doi: 10.1126/science.1101738. 
[159] Tanaka Y, Engelender S, Igarashi S, Rao RK, Wanner T, Tanzi RE, et al. Inducible expression of mutant alpha-synuclein decreases proteasome activity and increases sensitivity to mitochondria-dependent apoptosis. Human molecular genetics. 2001;10(9):919-26.

[160] Smith WW, Jiang H, Pei Z, Tanaka Y, Morita H, Sawa A, et al. Endoplasmic reticulum stress and mitochondrial cell death pathways mediate A53T mutant alphasynuclein-induced toxicity. Human molecular genetics. 2005;14(24):3801-11. doi: 10.1093/hmg/ddi396.

[161] Stefanis L, Larsen KE, Rideout HJ, Sulzer D, Greene LA. Expression of A53T mutant but not wild-type alpha-synuclein in PC12 cells induces alterations of the ubiquitindependent degradation system, loss of dopamine release, and autophagic cell death. The Journal of neuroscience : the official journal of the Society for Neuroscience. 2001;21(24):9549-60.

[162] Outeiro TF, Lindquist S. Yeast cells provide insight into alpha-synuclein biology and pathobiology. Science. 2003;302(5651):1772-5. doi: 10.1126/science.1090439.

[163] Dixon C, Mathias N, Zweig RM, Davis DA, Gross DS. Alpha-synuclein targets the plasma membrane via the secretory pathway and induces toxicity in yeast. Genetics. 2005;170(1):47-59. doi: 10.1534/genetics.104.035493.

[164] Flower TR, Chesnokova LS, Froelich CA, Dixon C, Witt SN. Heat shock prevents alpha-synuclein-induced apoptosis in a yeast model of Parkinson's disease. Journal of molecular biology. 2005;351(5):1081-100. doi: 10.1016/j.jmb.2005.06.060.

[165] Cooper AA, Gitler AD, Cashikar A, Haynes CM, Hill KJ, Bhullar B, et al. Alphasynuclein blocks ER-Golgi traffic and Rab1 rescues neuron loss in Parkinson's models. Science. 2006;313(5785):324-8. doi: 10.1126/science.1129462.

[166] Willingham S, Outeiro TF, DeVit MJ, Lindquist SL, Muchowski PJ. Yeast genes that enhance the toxicity of a mutant huntingtin fragment or alpha-synuclein. Science. 2003;302(5651):1769-72. doi: 10.1126/science.1090389.

[167] Douglas MR, Lewthwaite AJ, Nicholl DJ. Genetics of Parkinson's disease and parkinsonism. Expert review of neurotherapeutics. 2007;7(6):657-66. doi: 10.1586/14737175.7.6.657.

[168] Lo Bianco C, Schneider BL, Bauer M, Sajadi A, Brice A, Iwatsubo T, et al. Lentiviral vector delivery of parkin prevents dopaminergic degeneration in an alphasynuclein rat model of Parkinson's disease. Proceedings of the National Academy of Sciences of the United States of America. 2004;101(50):17510-5. doi: 10.1073/pnas.0405313101.

[169] Paterna JC, Leng A, Weber E, Feldon J, Bueler H. DJ-1 and Parkin modulate dopaminedependent behavior and inhibit MPTP-induced nigral dopamine neuron loss in mice. Molecular therapy : the journal of the American Society of Gene Therapy. 2007;15(4):698-704. doi: 10.1038/sj.mt.6300067.

[170] Von Coelln R, Thomas B, Savitt JM, Lim KL, Sasaki M, Hess EJ, et al. Loss of locus coeruleus neurons and reduced startle in parkin null mice. Proceedings of the National Academy of Sciences of the United States of America. 2004;101(29):107449. doi: 10.1073/pnas.0401297101.

[171] Goldberg MS, Fleming SM, Palacino JJ, Cepeda C, Lam HA, Bhatnagar A, et al. Parkindeficient mice exhibit nigrostriatal deficits but not loss of dopaminergic neurons. 
The Journal of biological chemistry. 2003;278(44):43628-35. doi: 10.1074/jbc.M308947200.

[172] Greene JC, Whitworth AJ, Kuo I, Andrews LA, Feany MB, Pallanck LJ. Mitochondrial pathology and apoptotic muscle degeneration in Drosophila parkin mutants. Proceedings of the National Academy of Sciences of the United States of America. 2003;100(7):4078-83. doi: 10.1073/pnas.0737556100.

[173] Greene JC, Whitworth AJ, Andrews LA, Parker TJ, Pallanck LJ. Genetic and genomic studies of Drosophila parkin mutants implicate oxidative stress and innate immune responses in pathogenesis. Human molecular genetics. 2005;14(6):799-811. doi: 10.1093/hmg/ddi074.

[174] Sang TK, Chang HY, Lawless GM, Ratnaparkhi A, Mee L, Ackerson LC, et al. A Drosophila model of mutant human parkin-induced toxicity demonstrates selective loss of dopaminergic neurons and dependence on cellular dopamine. The Journal of neuroscience : the official journal of the Society for Neuroscience. 2007;27(5):98192. doi: 10.1523/JNEUROSCI.4810-06.2007.

[175] Imai Y, Soda M, Inoue H, Hattori N, Mizuno Y, Takahashi R. An unfolded putative transmembrane polypeptide, which can lead to endoplasmic reticulum stress, is a substrate of Parkin. Cell. 2001;105(7):891-902.

[176] Shimura H, Schlossmacher MG, Hattori N, Frosch MP, Trockenbacher A, Schneider R, et al. Ubiquitination of a new form of alpha-synuclein by parkin from human brain: implications for Parkinson's disease. Science. 2001;293(5528):263-9. doi: 10.1126/science.1060627.

[177] LaVoie MJ, Ostaszewski BL, Weihofen A, Schlossmacher MG, Selkoe DJ. Dopamine covalently modifies and functionally inactivates parkin. Nature medicine. 2005;11(11):1214-21. doi: 10.1038/nm1314.

[178] Avraham E, Rott R, Liani E, Szargel R, Engelender S. Phosphorylation of Parkin by the cyclin-dependent kinase 5 at the linker region modulates its ubiquitin-ligase activity and aggregation. The Journal of biological chemistry. 2007;282(17):1284250. doi: 10.1074 /jbc.M608243200.

[179] Kitada T, Pisani A, Porter DR, Yamaguchi H, Tscherter A, Martella G, et al. Impaired dopamine release and synaptic plasticity in the striatum of PINK1-deficient mice. Proceedings of the National Academy of Sciences of the United States of America. 2007;104(27):11441-6. doi: 10.1073/pnas.0702717104.

[180] Clark IE, Dodson MW, Jiang C, Cao JH, Huh JR, Seol JH, et al. Drosophila pink1 is required for mitochondrial function and interacts genetically with parkin. Nature. 2006;441(7097):1162-6. doi: 10.1038/nature04779.

[181] Park J, Lee SB, Lee S, Kim Y, Song S, Kim S, et al. Mitochondrial dysfunction in Drosophila PINK1 mutants is complemented by parkin. Nature. 2006;441(7097):1157-61. doi: 10.1038/nature04788.

[182] Yang Y, Gehrke S, Imai Y, Huang Z, Ouyang Y, Wang JW, et al. Mitochondrial pathology and muscle and dopaminergic neuron degeneration caused by inactivation of Drosophila Pink1 is rescued by Parkin. Proceedings of the National Academy of Sciences of the United States of America. 2006;103(28):10793-8. doi: 10.1073/pnas.0602493103. 
[183] Pridgeon JW, Olzmann JA, Chin LS, Li L. PINK1 protects against oxidative stress by phosphorylating mitochondrial chaperone TRAP1. PLoS biology. 2007;5(7):e172. doi: 10.1371/journal.pbio.0050172.

[184] Silvestri L, Caputo V, Bellacchio E, Atorino L, Dallapiccola B, Valente EM, et al. Mitochondrial import and enzymatic activity of PINK1 mutants associated to recessive parkinsonism. Human molecular genetics. 2005;14(22):3477-92. doi: 10.1093/hmg/ddi377.

[185] Beilina A, Van Der Brug M, Ahmad R, Kesavapany S, Miller DW, Petsko GA, et al. Mutations in PTEN-induced putative kinase 1 associated with recessive parkinsonism have differential effects on protein stability. Proceedings of the National Academy of Sciences of the United States of America. 2005;102(16):5703-8. doi: 10.1073/pnas.0500617102.

[186] Andres-Mateos E, Perier C, Zhang L, Blanchard-Fillion B, Greco TM, Thomas B, et al. DJ-1 gene deletion reveals that DJ-1 is an atypical peroxiredoxin-like peroxidase. Proceedings of the National Academy of Sciences of the United States of America. 2007;104(37):14807-12. doi: 10.1073/pnas.0703219104.

[187] Park J, Kim SY, Cha GH, Lee SB, Kim S, Chung J. Drosophila DJ-1 mutants show oxidative stress-sensitive locomotive dysfunction. Gene. 2005;361:133-9. doi: 10.1016/j.gene.2005.06.040.

[188] Menzies FM, Yenisetti SC, Min KT. Roles of Drosophila DJ-1 in survival of dopaminergic neurons and oxidative stress. Current biology : CB. 2005;15(17):157882. doi: 10.1016/j.cub.2005.07.036.

[189] Meulener M, Whitworth AJ, Armstrong-Gold CE, Rizzu P, Heutink P, Wes PD, et al. Drosophila DJ-1 mutants are selectively sensitive to environmental toxins associated with Parkinson's disease. Current biology : CB. 2005;15(17):1572-7. doi: 10.1016/j.cub.2005.07.064.

[190] Meulener MC, Xu K, Thomson L, Ischiropoulos H, Bonini NM. Mutational analysis of DJ-1 in Drosophila implicates functional inactivation by oxidative damage and aging. Proceedings of the National Academy of Sciences of the United States of America. 2006;103(33):12517-22. doi: 10.1073/pnas.0601891103.

[191] West AB, Moore DJ, Biskup S, Bugayenko A, Smith WW, Ross CA, et al. Parkinson's disease-associated mutations in leucine-rich repeat kinase 2 augment kinase activity. Proceedings of the National Academy of Sciences of the United States of America. 2005;102(46):16842-7. doi: 10.1073/pnas.0507360102.

[192] West AB, Moore DJ, Choi C, Andrabi SA, Li X, Dikeman D, et al. Parkinson's diseaseassociated mutations in LRRK2 link enhanced GTP-binding and kinase activities to neuronal toxicity. Human molecular genetics. 2007;16(2):223-32. doi: $10.1093 / \mathrm{hmg} / \mathrm{ddl} 471$.

[193] Greggio E, Lewis PA, van der Brug MP, Ahmad R, Kaganovich A, Ding J, et al. Mutations in LRRK2/dardarin associated with Parkinson disease are more toxic than equivalent mutations in the homologous kinase LRRK1. Journal of neurochemistry. 2007;102(1):93-102. doi: 10.1111/j.1471-4159.2007.04523.x.

[194] MacLeod D, Dowman J, Hammond R, Leete T, Inoue K, Abeliovich A. The familial Parkinsonism gene LRRK2 regulates neurite process morphology. Neuron. 2006;52(4):587-93. doi: 10.1016/j.neuron.2006.10.008. 
[195] Ito G, Okai T, Fujino G, Takeda K, Ichijo H, Katada T, et al. GTP binding is essential to the protein kinase activity of LRRK2, a causative gene product for familial Parkinson's disease. Biochemistry. 2007;46(5):1380-8. doi: 10.1021/bi061960m.

[196] Smith WW, Pei Z, Jiang H, Dawson VL, Dawson TM, Ross CA. Kinase activity of mutant LRRK2 mediates neuronal toxicity. Nature neuroscience. 2006;9(10):1231-3. doi: $10.1038 / \mathrm{nn} 1776$.

[197] Langston JW. The Parkinson's complex: parkinsonism is just the tip of the iceberg. Ann Neurol. 2006;59(4):591-6. doi: 10.1002/ana.20834.

[198] Selikhova M, Williams DR, Kempster PA, Holton JL, Revesz T, Lees AJ. A clinicopathological study of subtypes in Parkinson's disease. Brain. 2009;132(Pt 11):294757. doi: awp234 [pii] 10.1093/brain/awp234.

[199] Marsden CD. Studies on the normal and disordered human motor cortex. Electroencephalogr Clin Neurophysiol Suppl. 1982;36:430-4.

[200] Jankovic J. Parkinson's disease and movement disorders: moving forward. Lancet Neurol. 2008;7(1):9-11. doi: S1474-4422(07)70302-2 [pii] 10.1016/S14744422(07)70302-2.

[201] Voon V, Krack P, Lang AE, Lozano AM, Dujardin K, Schupbach M, et al. A multicentre study on suicide outcomes following subthalamic stimulation for Parkinson's disease. Brain. 2008;131(Pt 10):2720-8. doi: awn214 [pii] 10.1093/brain/awn214.

[202] Pechevis M, Clarke CE, Vieregge P, Khoshnood B, Deschaseaux-Voinet C, Berdeaux G, et al. Effects of dyskinesias in Parkinson's disease on quality of life and healthrelated costs: a prospective European study. Eur J Neurol. 2005;12(12):956-63. doi: ENE1096 [pii] 10.1111/j.1468-1331.2005.01096.x.

[203] Kempster PA, O'Sullivan SS, Holton JL, Revesz T, Lees AJ. Relationships between age and late progression of Parkinson's disease: a clinico-pathological study. Brain. 2010;133(Pt 6):1755-62. doi: awq059 [pii] 10.1093/brain/awq059.

[204] Emre M, Aarsland D, Brown R, Burn DJ, Duyckaerts C, Mizuno Y, et al. Clinical diagnostic criteria for dementia associated with Parkinson's disease. Mov Disord. 2007;22(12):1689-707; quiz 837. doi: 10.1002/mds.21507.

[205] Siderowf A, Xie SX, Hurtig H, Weintraub D, Duda J, Chen-Plotkin A, et al. CSF amyloid \{beta\} 1-42 predicts cognitive decline in Parkinson disease. Neurology. 2010;75(12):1055-61. doi: WNL.0b013e3181f39a78 [pii] 10.1212/WNL.0b013e3181f39a78.

[206] Hauptmann C, Tass PA. Therapeutic rewiring by means of desynchronizing brain stimulation. Biosystems. 2007;89(1-3):173-81. doi: S0303-2647(06)00256-5 [pii] 10.1016/j.biosystems.2006.04.015.

[207] Weaver FM, Follett K, Stern M, Hur K, Harris C, Marks WJ, Jr., et al. Bilateral deep brain stimulation vs best medical therapy for patients with advanced Parkinson disease: a randomized controlled trial. JAMA. 2009;301(1):63-73. doi: 301/1/63 [pii] 10.1001/jama.2008.929.

[208] Williams A, Gill S, Varma T, Jenkinson C, Quinn N, Mitchell R, et al. Deep brain stimulation plus best medical therapy versus best medical therapy alone for advanced Parkinson's disease (PD SURG trial): a randomised, open-label trial. Lancet Neurol. 2010;9(6):581-91. doi: S1474-4422(10)70093-4 [pii] 10.1016/S14744422(10)70093-4. 
[209] Smeding HM, Speelman JD, Huizenga HM, Schuurman PR, Schmand B. Predictors of cognitive and psychosocial outcome after STN DBS in Parkinson's Disease. J Neurol Neurosurg Psychiatry. 2011;82(7):754-60. doi: jnnp.2007.140012 [pii] 10.1136/jnnp.2007.140012.

[210] Strutt AM, Simpson R, Jankovic J, York MK. Changes in cognitive-emotional and physiological symptoms of depression following STN-DBS for the treatment of Parkinson's disease. Eur J Neurol. 2011. doi: 10.1111/j.1468-1331.2011.03447.x.

[211] Voon V, Saint-Cyr J, Lozano AM, Moro E, Poon YY, Lang AE. Psychiatric symptoms in patients with Parkinson disease presenting for deep brain stimulation surgery. J Neurosurg. 2005;103(2):246-51. doi: 10.3171/jns.2005.103.2.0246.

[212] Ory-Magne F, Brefel-Courbon C, Simonetta-Moreau M, Fabre N, Lotterie JA, Chaynes $\mathrm{P}$, et al. Does ageing influence deep brain stimulation outcomes in Parkinson's disease? Mov Disord. 2007;22(10):1457-63. doi: 10.1002/mds.21547.

[213] Parent BA, Cho SW, Buck DG, Nalesnik MA, Gamblin TC. Spontaneous rupture of hepatic artery aneurysm associated with polyarteritis nodosa. Am Surg. 2010;76(12):1416-9.

[214] Merola A, Zibetti M, Angrisano S, Rizzi L, Lanotte M, Lopiano L. Comparison of subthalamic nucleus deep brain stimulation and Duodopa in the treatment of advanced Parkinson's disease. Mov Disord. 2011;26(4):664-70. doi: $10.1002 /$ mds.23524.

[215] Lindvall O, Kokaia Z, Martinez-Serrano A. Stem cell therapy for human neurodegenerative disorders-how to make it work. Nat Med. 2004;10 Suppl:S42-50. doi: 10.1038/nm1064 nm1064 [pii].

[216] Freed WJ, Vawter MP. Microarrays: applications in neuroscience to disease, development, and repair. Restor Neurol Neurosci. 2001;18(2-3):53-6.

[217] Rhee YH, Ko JY, Chang MY, Yi SH, Kim D, Kim CH, et al. Protein-based human iPS cells efficiently generate functional dopamine neurons and can treat a rat model of Parkinson disease. J Clin Invest. 2011;121(6):2326-35. doi: 45794 [pii] 10.1172/JCI45794.

[218] Merola A, Zibetti M, Angrisano S, Rizzi L, Ricchi V, Artusi CA, et al. Parkinson's disease progression at 30 years: a study of subthalamic deep brain-stimulated patients. Brain. 2011;134(Pt 7):2074-84. doi: awr121 [pii] 10.1093/brain/awr121.

[219] Bjorklund A, Lindvall O. Parkinson disease gene therapy moves toward the clinic. Nat Med. 2000;6(11):1207-8. doi: 10.1038/81291.

[220] Kirik D, Georgievska B, Bjorklund A. Localized striatal delivery of GDNF as a treatment for Parkinson disease. Nat Neurosci. 2004;7(2):105-10. doi: 10.1038/nn1175 nn1175 [pii].

[221] Ramaswamy S, Soderstrom KE, Kordower JH. Trophic factors therapy in Parkinson's disease. Prog Brain Res. 2009;175:201-16. doi: S0079-6123(09)17514-3 [pii] 10.1016/S0079-6123(09)17514-3.

[222] Klein AA, Arrowsmith JE. Should routine pre-operative testing be abandoned? Anaesthesia. 2010;65(10):974-6. doi: 10.1111/j.1365-2044.2010.06503.x.

[223] Gill SS, Patel NK, Hotton GR, O'Sullivan K, McCarter R, Bunnage M, et al. Direct brain infusion of glial cell line-derived neurotrophic factor in Parkinson disease. Nat Med. 2003;9(5):589-95. doi: 10.1038/nm850 nm850 [pii]. 
[224] Lang AE, Gill S, Patel NK, Lozano A, Nutt JG, Penn R, et al. Randomized controlled trial of intraputamenal glial cell line-derived neurotrophic factor infusion in Parkinson disease. Ann Neurol. 2006;59(3):459-66. doi: 10.1002/ana.20737.

[225] Bartus RT, Herzog CD, Chu Y, Wilson A, Brown L, Siffert J, et al. Bioactivity of AAV2neurturin gene therapy (CERE-120): differences between Parkinson's disease and nonhuman primate brains. Mov Disord. 2011;26(1):27-36. doi: 10.1002/mds.23442.

[226] Decressac M, Ulusoy A, Mattsson B, Georgievska B, Romero-Ramos M, Kirik D, et al. GDNF fails to exert neuroprotection in a rat \{alpha\}-synuclein model of Parkinson's disease. Brain. 2011;134(Pt 8):2302-11. doi: awr149 [pii] 10.1093/brain/awr149. 


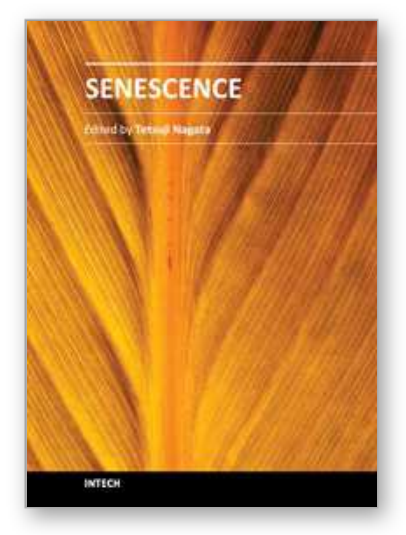

\author{
Senescence \\ Edited by Dr. Tetsuji Nagata
}

ISBN 978-953-51-0144-4

Hard cover, 850 pages

Publisher InTech

Published online 29, February, 2012

Published in print edition February, 2012

The book "Senescence" is aimed to describe all the phenomena related to aging and senescence of all forms of life on Earth, i.e. plants, animals and the human beings. The book contains 36 carefully reviewed chapters written by different authors, aiming to describe the aging and senescent changes of living creatures, i.e. plants and animals.

\title{
How to reference
}

In order to correctly reference this scholarly work, feel free to copy and paste the following:

Jing-ye Zhou, Yong Yu, Xian-Lun Zhu, Chi-Ping Ng, Gang Lu and Wai-Sang Poon (2012). Parkinson's Disease: Insights from the Laboratory and Clinical Therapeutics, Senescence, Dr. Tetsuji Nagata (Ed.), ISBN: 978-953-51-0144-4, InTech, Available from: http://www.intechopen.com/books/senescence/insights-from-thelaboratory-and-clinical-therapeutics

\section{INTECH}

open science | open minds

\author{
InTech Europe \\ University Campus STeP Ri \\ Slavka Krautzeka 83/A \\ 51000 Rijeka, Croatia \\ Phone: +385 (51) 770447 \\ Fax: +385 (51) 686166 \\ www.intechopen.com
}

\author{
InTech China \\ Unit 405, Office Block, Hotel Equatorial Shanghai \\ No.65, Yan An Road (West), Shanghai, 200040, China \\ 中国上海市延安西路65号上海国际贵都大饭店办公楼405单元 \\ Phone: +86-21-62489820 \\ Fax: $+86-21-62489821$
}


(C) 2012 The Author(s). Licensee IntechOpen. This is an open access article distributed under the terms of the Creative Commons Attribution 3.0 License, which permits unrestricted use, distribution, and reproduction in any medium, provided the original work is properly cited. 